Island Studies Journal, Vol. 11, No. 2, 2016, pp. 637-650

\title{
The genre of islands: Popular fiction and performative geographies
}

Ralph Crane

University of Tasmania

Australia

Ralph.Crane@utas.edu.au

and

Lisa Fletcher

University of Tasmania

Australia

Lisa.Fletcher@utas.edu.au

ABSTRACT: To date, studies of the contribution literature makes to ideas about islands have concentrated on "high" literature. This has left unexamined the largest proportion of literature featuring islands. If one of the goals of island studies is to interrogate prevailing ideas about "islandness," then the islands that crowd the storyworlds of popular genres merit close attention. This article focuses on popular fiction to advocate "performative geographies" as a key concept for island studies of literature, and indeed other domains of culture. Popular genres are undeniably sources of distraction and entertainment for billions of readers. However, they are also systems of meaning, which have an immeasurable impact on our geographical awareness and imagination. This article uses critical snapshots of Anglophone island-set crime fiction and popular romance fiction to show the meta-geographical potential of popular novels as they both depict and reflect on islands as performative geographies, or spaces that make and unmake individual and social identities.

Keywords: crime fiction, islands, performative geographies, popular fiction, popular romance fiction, setting

(C) 2016 - Institute of Island Studies, University of Prince Edward Island, Canada

\section{Introduction}

"Popular fiction is frequently thought of as those books that everyone reads" (Glover and McCracken, 2012, p. 1); and islands are everywhere in popular fiction.

The many small islands off the coast of Great Britain provide the perfect geography for whodunits and crime thrillers including Ann Cleeves's Shetland series, Peter May's Lewis trilogy, set in the Outer Hebrides, and Chris Ewan's thrillers Safe House (2012), and Dark Tides (2014), both set on the Isle of Man, which is also the setting for Margaret Evans Porter's historical romance series, The Islanders. The Mediterranean provides the island locales for Anne Zouroudi's seven-volume Mysteries of the Greek Detective series, and for numerous thrillers including Chris Allen's Hunter (2012), the second book of his Intrepid Series, which largely takes place on Malta and Gozo. Sharon Bolton sets her thriller Little Black Lies (2012) in the Falkland Islands, while Clive Cussler features Antarctic islands in several of his Dirk 


\section{R. Crane \& L. Fletcher}

Pitt thrillers, including Shock Wave (1996). Emily Snow's romance, Tidal (2012), and Chip Hughes's Murder on Moloka'i (2004) take readers to several islands in the Hawaiian archipelago. Nick Stone's macabre Max Mingus thriller, Mr Clarinet (2006), is set in Haiti, while David Poyer chooses Hatteras Island off the North Carolina coast for the first of his Tilley Galloway underwater thrillers. Islands (frequently imaginary) off America's Atlantic coast are also popular destinations for romance writers including Nora Roberts, whose Three Sisters Island lies a short ferry ride from Salem, Massachusetts; Virginia Kantra, whose Dare Island lies off the coast of North Carolina; and Helen Brenna, who describes her Mirabelle Island, Wisconsin as a cross between Mackinac Island, Michigan, and Wisconsin's Apostle Islands (Brenna, 2012, location 22). Mystery series by John Enright, G. W. Kent, and Marianne Wheelaghan are set on various islands in the Pacific, while the heroine of Island Paradise (1992), by contemporary romance writer Barbara McMahon, is stranded on an exotic island in the South Pacific, and three of Valerie Parv's romance series are set in her "idyllic invented kingdom of Carramer" (Parv, 2004, location 549) in the Pacific.

As these examples from crime and romance fiction demonstrate, islands, real and imagined, jostle for space on the map of popular fiction. Yet to date, studies of the contribution literature makes to ideas about islands have concentrated on literary classics, many of which were the popular fictions of their time: from William Shakespeare's The Tempest (1611) to Daniel Defoe's Robinson Crusoe (1719) and from Robert Michael Ballantyne's The Coral Island (1857) to William Golding's Lord of the Flies (1954). Further, the few published studies of islands in contemporary fiction focus on what Ken Gelder calls "literary fiction or Literature" (Gelder, 2004, p. 1) (with a capital "L"), and on postcolonial literatures of the Pacific and the Caribbean. This has left unexamined the largest proportion of literature featuring islands.

If one of the goals of island studies is to interrogate prevailing ideas about "islandness," then the islands that crowd the storyworlds of popular genres merit closer attention. This paper focuses on genre fiction to advocate "performative geographies" as a key concept for island studies approaches to literature - and indeed other fields of cultural production. It is time to grapple with the roles popular fiction play in the world of islands.

What is popular fiction and why should island studies take it seriously? While it might be "tempting," as Christine Berberich explains, to define popular fiction as writing that is "read and, crucially, enjoyed by many readers [...], it is not that simple" (Berberich, 2015, pp. 2-3). In relation to fiction, the adjective "popular" carries a heavy load: it indicates, most obviously, that some texts are more widely liked and read than others, at the same time as connoting that some texts are inferior to, or less worthy of, high regard than others. The relationship between wide (or mass) readership and low quality is typically assumed to be causal, as labels such as "low-brow literature," "trash fiction," and "pulp fiction" suggest. Popular fiction, in short, is always defined in relation to the organisation of its market and the proclivities of its readers, both of which are best mapped with reference to the question of genre.

Glover and McCracken write that "popular fiction is primarily based upon a limited number of forms or genres of narrative pleasure, such as suspense, romantic complications, bodily horror or futuristic speculation" (Glover \& McCracken, 2012, p. 2). For Gelder, "[p]opular fiction is, essentially, genre fiction" (Gelder, 2004, p. 1). The division of the broader literary field into Literature and popular fiction in the closing decades of the nineteenth century went hand in hand with the development of the "modern system of genre 
fiction" (Glover, 2012, p. 17) which segregates the bulk of published fiction into distinct categories (crime, fantasy, horror, romance, science fiction), sub-categories (cozy mysteries, epic fantasy, historical romance, space opera), and blended categories (dark fantasy, romantic suspense). Importantly for us, the genre system emerged during the decades when the nineteenth-century adventure novel reached its apotheosis as a literary form and commercial product; it is well known that from The Coral Island to Treasure Island and beyond, islands are everywhere in the history of adventure fiction. What is perhaps less well known is that if one were to create a map of the world as imagined by the most influential popular novels of the late nineteenth and early twentieth centuries across all genres, it would be crowded with islands. Over the course of more than a century, popular fiction has mapped a worldembracing archipelago that scholars have barely begun to explore. The atlas of real-andimagined islands would be even richer and thicker were we also to consider the islands of fictional other worlds in fantasy and science fiction. So islands should matter to popular fiction studies, and popular fiction should matter to island studies, but not just because islands are stock settings for genre fiction.

As we have argued elsewhere (Crane \& Fletcher 2014, 2016), the settings of novels are more than passive backdrops or stages against which characters interact and events unfold. Like Sheila Hones, we are interested in the ways "narrative generates geographies" (Hones, 2011 , p. 687). This involves thinking of the geographical setting of any text as more than "container space." Instead, "texts and space, fiction and location, might be understood as inseparable and co-productive" (Hones, 2011, p. 686). Examining popular fiction through the lens of island studies reveals that the meanings produced and circulated by genre novels are profoundly contingent on "placial" thinking, to use Edward Casey's term. Genre fiction is emphatically placial; that is, it is anchored in the knowledge that place is the condition for the construction and telling of stories, and thus treats as axiomatic the assertion that "[p]lace is primary because it is the experiential fact of our existence" (Cresswell, 2004, p. 32). Further, genre fiction represents our experience of place as simultaneously phenomenological and cultural. Elizabeth Leane shows, in her study of thrillers set in Antarctica, that "all places are hybrids of the literal and the literary," and, paradoxically, the more seemingly "natural" a place, the more reliant we become on its cultural representation (Leane, 2016, p. 27). Genre fiction recognises that particular kinds of geographies generate particular kinds of stories and so exploits the seemingly natural fit between types of place and types of narrative. The reverse is also true: some types of stories require particular types of settings. Genre and geography are mutually informing, but what does this mean for island (literary) studies?

For the most part studies of the significance of setting in fiction have produced close textual analyses of the representation of place or, to a lesser extent, of the spatial relations which organise and progress narratives, and this has also been the case in island studies approaches to literature. However, as Hones argues, the act of reading any text is a "spatial event" which connects "people, places, times, networks, communities" (Hones, 2008, p. 1301). This is an invaluable insight for thinking about genre fiction, not least because of the intensely spatial tropes which prevail in the wider discourse about reading popular novels. Wherever one actually reads a genre novel - from Steig Larsson's Girl with a Dragon Tattoo (2005) to E. L. James's Fifty Shades of Grey (2011) - that reading experience is framed by ideas of transit and escape. Not only are terms like "airport fiction," "holiday reading," and, indeed, "beach reading" standard (and value-laden) classifications for the books we discuss in this paper, but the appeal of popular genres is almost always explained with recourse to 


\section{R. Crane \& L. Fletcher}

metaphors of travel, or more broadly of mobility. From blurbs to blogs and throughout scholarly criticism, genre novels are frequently described as vehicles which transport readers elsewhere, or facilitate their virtual escape from reality. Popular novels or "page-turners" are also characterised by their fast narrative pace and the speed with which they can be read; this is both a temporal and spatial idea as it understands reading as a journey through time and space. Hones encourages literary geographers to consider the material circumstances of reading: where people read and how the physical encounter with or use of a book is a spatial experience. For our purposes, however, her description of the geography of reading is too inflected by high literary assumptions. In Hones's analysis, when an individual reader opens a text, they initiate an "unpredictable and unique" spatial event which connects them to the writer (Hones, 2008, p. 1301). When a reader opens a genre text, however, they initiate a spatial event which is largely defined by its familiarity and predictability. As Hones explains, when considered spatially, reading a text is "scattered across time and space, both human and non-human, absent and present" (Hones, 2008, p. 1302) but the event of reading a genre text is largely mapped in advance. Turning our attention to island genres reveals the extent to which the reality and fiction of islands are less opposites than the "sides" of a Möbius strip.

In her 2011 critical survey of island studies, Lisa Fletcher proposes the concept of "performative geographies" as a solution to the impasse she detects in the field's privileging of "real islands" as its proper object of study (Fletcher, 2011). She argues for approaches to reading islands as sites of (and in) cultural production which recognise that "human encounters with physical space are always already managed by our position in linguistic and cultural systems of representation" (Fletcher, 2011, p. 19). Genre is one such system. As Fletcher suggests, descriptions of "social and material reality" are performative to the extent that they "create the vectors by which we navigate and comprehend that reality" (Fletcher, 2011, p. 26). Crucially, however, to say that popular fictional geographies are performative is not to say that novels impose meaning on islands as tabula rasae, nor more extremely, is it to say that islands only exist in and through language. Instead, a theory of performative geographies grants islands metaphorical agency by acknowledging that islands are not passive players in the stories we tell about them, but rather that they participate in the production of meaning.

Time and again both crime and romance fictions depict characters approaching a small island by sea or air. These ubiquitous scenes of arrival, which typically appear early in the text, offer the protagonist as an avatar for the reader entering the storyworld. For example, as John Callum's plane "neared the Faroes and circled them," in Craig Robertson's murder mystery, The Last Refuge (2014), the "lush green mountaintops that emerged suddenly and threateningly from the clouds" and "the rugged crags [...] looming up from the angry sea" (Robertson, 2014, p. 7) presage the events that follow. G. W. Kent's first Sergeant Kella and Sister Conchita mystery, Devil-Devil (2011), opens with a scene of arrival as the feisty nun struggles to beach her dugout canoe. As well as introducing Sister Conchita to the reader as an outsider "fight[ing] the sea alone" (Kent, 2011, p. 2) this event also heralds the sea-island nexus that is pivotal in these Solomon Islands mysteries. And while not depicting the arrival of a character per se, the opening words of David Owen's first Pufferfish mystery, Pig's Head (1994) - "You cannot enter this state by road." (Owen, 2003, p. 1) - signal the "sea-locked" (Owen, 2003, p. 2) geography of Tasmania and entice readers into the insular storyworld. In the first chapter of Nora Roberts's Treasures Lost, Treasures Found (1986), Kate Hardy gets out of her car and stands at the rail of the ferry to Ocracoke Island, North Carolina. She watches the "gulls swoop and the tiny uninhabited islands pass by," and feels "a sense of 
homecoming" (Roberts, 1986, location 228). The first page of Parv's Tasmanian Devil (1989) mentions Tasmania, Macquarie Island, Bruny Island, and the fictional Frere Island, "a rocky little island in the Tasman Sea" that the heroine has just inherited: "As the green-clad mound of Frere Island appeared as a speck on the horizon, Evelyn Consett suppressed a shiver. It looked primitive and cold" (Parv, 1989, p. 5). Similarly, Zöe Archer's steampunk romance, Skies of Gold (2013), begins with a description of the view from a steam ferry approaching a fictional island in the Outer Hebrides: "A dark serrated shape pushed up from the gray horizon" (Archer, 2013, location 47). The heroine shivers and tells herself, "It's only an isolated island. Exactly where you want to be" (Archer, 2013, location 47). These exemplary scenes of island arrival are both highly conventional and make claims for the particularity or uniqueness of the people and places they depict. They therefore function as analogues for the spatial event of reading a crime or romance novel, which is always simultaneously conventional and singular, social and individual.

Importantly, in the field of popular fiction the consistency of tropes of "islandness" does not weaken these texts. Genres thrive on shared conventions of representation. Turning to genre fiction to think about the meaning and significance of islands in contemporary culture runs against the grain of nissological approaches advocated by critics such as Grant McCall and Christian Depraetere, because of their insistence on studying "islands on their own terms" (McCall, 1994, p. 2). It almost goes without saying that countless genre novels set on islands, both in their content and through their marketing and reception, exemplify the perspective which McCall encapsulates with his statement, "[c]ontinentals covet islands" (McCall, 1996). We think it is incumbent on island studies scholars to scrutinise those texts and discourses where we might expect to find the island deployed and redeployed as, in Pete Hay's words, a "robust and tenaciously familiar metaphor and literary trope" (Hay, 2006, p. 21). However, while they might be familiar, genre islands are not as simple as they may at first appear. The novels we discuss in this paper offer rich examples of the meta-geographical potential of genre fictions as they both depict and reflect on islands as performative geographies, or spaces that make and unmake individual and social identities. To advance this argument, we offer a critical survey of contemporary island-set crime fiction as a means of analysing the habits of the conceptualization and representation of islands in popular fiction. We then identify contemporary romance series set on small islands as a twenty-first-century genre cycle which raises questions about the function of islands in the popular imagination.

P. D. James recognizes this potential in her Adam Dalgliesh mystery, The Lighthouse (2005). Following the suspicious death of a distinguished writer, Dalgliesh and his investigatory team fly out to the crime site, the fictitious Combe Island:

almost at once Combe Island lay beneath them, as unexpectedly as if it had risen from the waves, multi-coloured and as sharply defined as a coloured photograph, its silver granite cliffs towering from a white boiling of foam. Dalgliesh reflected that it was impossible to view an offshore island from the air without a quickening of the spirit. Bathed in autumnal sunshine there stretched a sea-estranged other world, deceptively calm but rekindling boyhood memories of fictional mystery, excitement and danger. Every island to a child is a treasure island. Even to an adult mind Combe, like every small island, sent out a paradoxical message: the contrast between its calm isolation and the latent power of the sea which both protected and threatened its self-contained alluring peace (James, 2005, p. 95). 


\section{R. Crane \& L. Fletcher}

The physical geography of the island, captured in the image of the granite cliffs rising from the boiling sea, is overwritten by layers of metaphor that redefine the island against a history of genre fiction, from Stevenson's Treasure Island to the present day. The small islands we find in popular fiction, whether they are based on real places or invented, are at once governed by geographical verisimilitude and genre conventions.

As is typical of "crime islands," Combe Island is a circumscribed or secure space where no one can land unseen and in which the number of potential suspects is carefully contained; it is also simultaneously a space where the topography can be manipulated to meet the needs of the clue-puzzle (or locked-room) genre to which it belongs. In other words, crime fiction takes for granted existing tropes (containment, restricted access, limited suspects) and transfers them to island locations where the topography becomes an active player in the story. The degree to which an island in genre fiction can seem to take on agency is apparent in the penultimate paragraph of the novel as Detective Inspector Kate Miskin and her colleagues depart the island following the conclusion of the case,

Kate gazed down at the familiar buildings which looked as compact as models or children's toys: the great curved windows of Combe House, the stable block where she had lodged, Seal Cottage with its memories of their late-night conferences, the square chapel, still with that stain of blood, and the brightly coloured lighthouse with its red cupola, the most charming toy of all. Combe Island had changed her in ways which she couldn't yet understand, but she knew she would never see it again (James, 2005, p. $323)$.

Here, the island's performativity, its ability to transform the human subject, that has been implicit throughout the novel, is made explicit.

The Isle of Man is similarly invested with agency in Chris Ewan's psychological crime thriller Dark Tides (2014). In an inner narrative, the murderer "wonder[s] what it is about the island that makes its inhabitants feel so secure" (Ewan, 2014, p. 170), before answering his own rhetorical question: "Naturally, the low crime rate is important, but there must be something else that reassures people on a subliminal level. Perhaps it's the island's geographic isolation" (Ewan, 2014, p. 170). In Ewan's novel the geography of the remote island is credited with the facility to influence the mindsets and actions of his characters. In Sharon Bolton's Little Black Lies the Falkland Islands are even more clearly anthropomorphized, or attributed consciousness: "The child has been missing for nearly thirty hours now and it feels as though the islands are waiting for something" (Bolton, 2015, p. 76). That sense of the islands participating in the drama is also evident in Bolton's Sacrifice (2008), set on the Shetland Islands,

Like black-cowled monks, frozen in prayer, [the stacks] stood in silence and watched us passing.

And something weird had got into my head that night, because it seemed to me these rocks were sentient, that the human drama taking place before them was hardly new, and that they watched, coldly curious, waiting to see how the act would be played out this time (Bolton, 2008, p. 498). 
This passage captures perfectly the tension between generality ("the human drama ... was hardly new") and particularity at the heart of genre islands ("how the act would be played out this time"). While the Falkland Islands and the Shetland Islands, respectively, wait and watch, Bolton leaves the reader in no doubt that they have the power to direct the drama unfolding before them should they wish to do so, and indeed in these novels, as in much island crime fiction, insular geography plays an active part in shaping a particular kind of story.

The four novels in John Enright's Jungle Beat Mystery Series featuring Detective Sergeant Apelu Soifua - Pago Pago Tango (2012), Fire Knife Dancing (2013), The Dead Don't Dance (2014), and Blood Jungle Ballet (2014) - are all set in American Samoa, "[a] chain of six tiny islands with a total land area of seventy-six square miles, [which] for more than a hundred years now had been a 'possession' of the United States of America, five thousand open ocean miles away" (Enright, 2013, p. 26). In placial terms, the islands are isolated from the main, at once contained spaces, and liminal spaces. They function as "contact zones" to use Mary Louise Pratt's term (Pratt, 1992), where the Samoan-born, American-bred detective must negotiate the boundary between Samoan and American cultures, between traditional and modern methods, and between the island and the continent.

Figure 1: Front Cover: John Enright, The Dead Don't Dance (Seattle: Thomas \& Mercer, 2014).

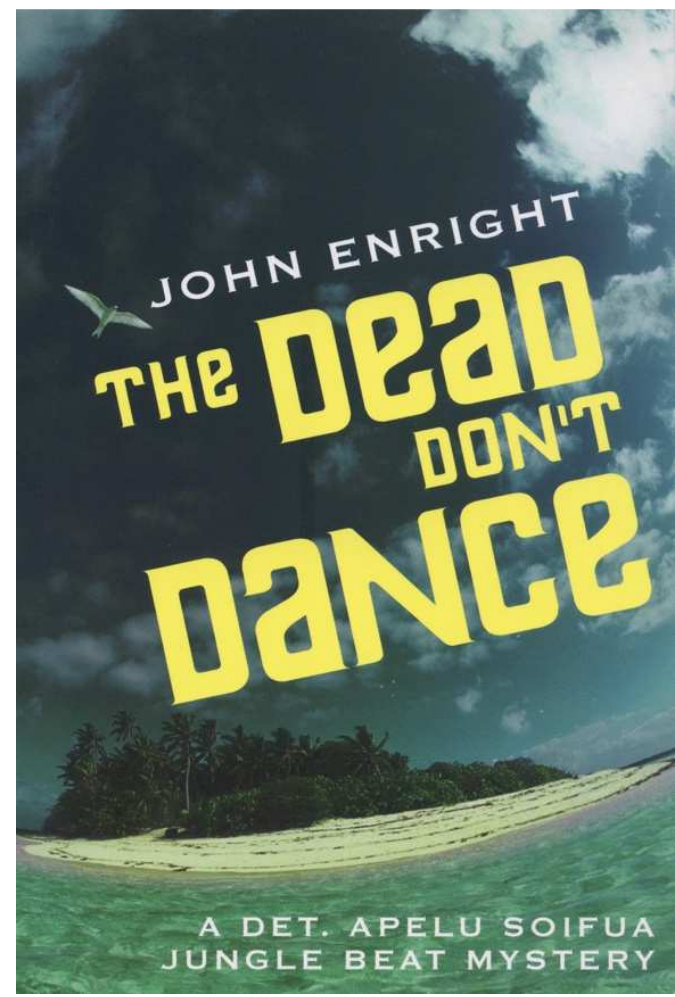

Enright's detective is American trained, but frequently relies on both cultural and physical geographical knowledge of the islands to solve the crimes he encounters. The actual geography of American Samoa is thus a critical element in the stories, particularly in the third volume of the series, The Dead Don't Dance. The illustration on the cover of this novel 


\section{R. Crane \& L. Fletcher}

(Figure 1) depicts a palm-fringed beach on a small island, seemingly devoid of any sign of human habitation. This image immediately highlights the iconography of islands, conjuring the ideas of remoteness and escape, imaginatively or literally (or even imaginatively and literally), and inviting the possibility of reading genre fiction on what Louis Turner and John Ash have termed "the pleasure periphery" (Turner \& Ash, 1975). The fish-eye perspective draws the reader's attention to the beach and the littoral zone, while the dark clouds massing across the upper two-thirds of the image gesture to the drama that is about to descend on the island. The inclusion of a literary map of Ofu and Olosega Islands (Figure 2), the principal setting of the novel, and much smaller-scale inset maps of the position of these islands within American Samoa and of the position of the Samoan Islands in the Pacific Ocean, explicitly locate the characters and events of Enright's mystery in relation to real places and histories.

\section{Figure 2: Map. John Enright, The Dead Don't Dance (Seattle: Thomas \& Mercer, 2014).}

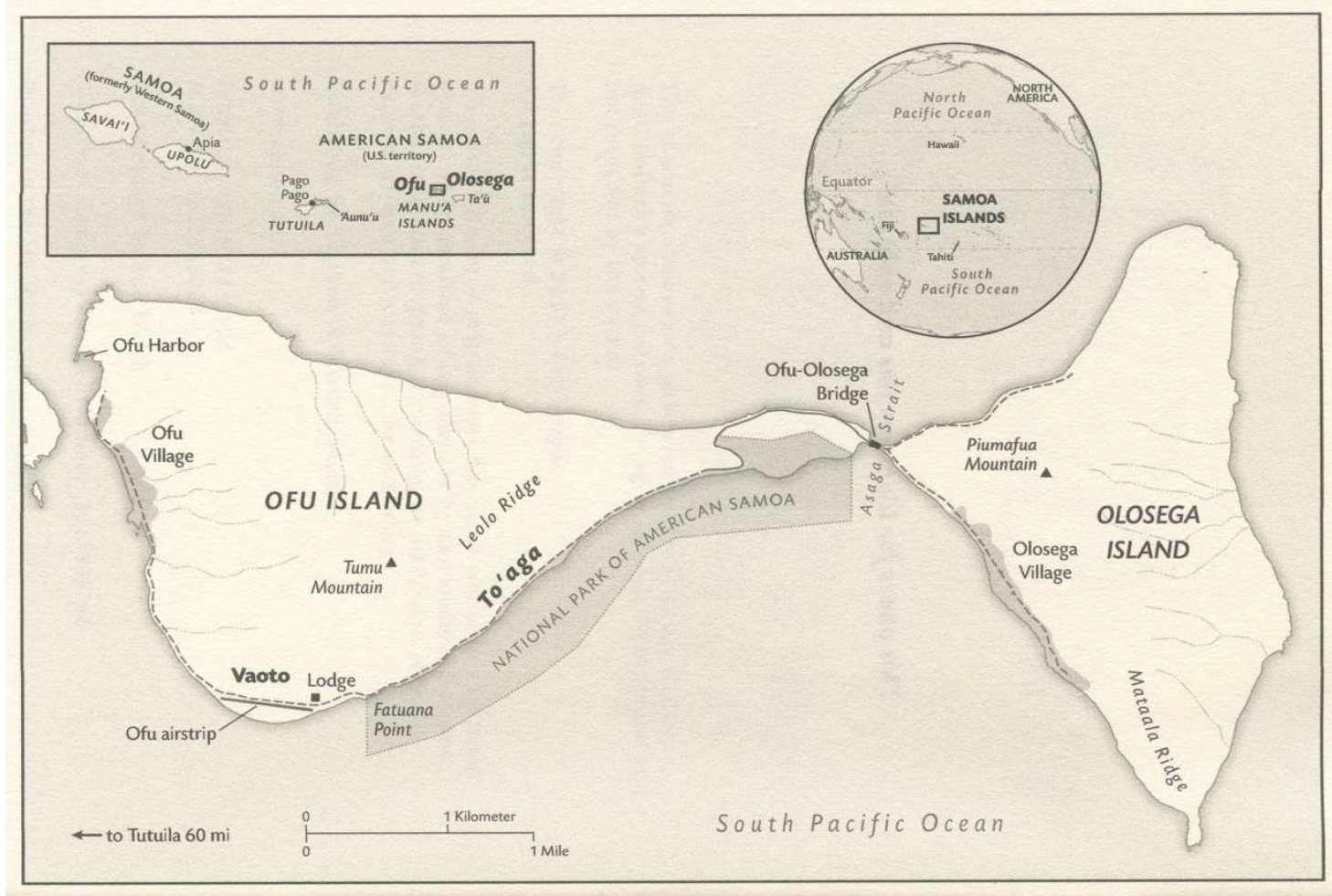

This visual paratext, which faces the opening page of the novel, is not referenced in the narrative: its purpose is to identify the region where the action of the novel takes place, to introduce the islands to readers who may not be familiar with the geography of American Samoa, and to provide a sense of scale, through the map scale provided in the bottom left, and through signposting the distance to Tutuila, the largest and main island of American Samoa. It clearly signals the fact that the narrative about to unfold will be a geographical one in which, as is typical of setting-driven crime fiction, the itineraries of characters both structure the story of the investigation and invite readers to engage with questions germane to spatial literary studies broadly (see, for example, Pezzotti, 2012, and Schmid, 2012), and island studies more specifically. Further, given that the twin islands of Ofu-Olosega can be found on any map of the region, geographical verisimilitude is foregrounded as a key element in the novel. For 
Robert T. Tally Jr., "[t]o draw a map is to tell a story, in many ways, and vice versa" (Tally Jr., 2013, p. 4). In short, in terms of performative geographies, this map is an invitation to follow the movements of imagined characters between and within particular island settings and a promise that neither the topography nor the customs of the islands will be altered to suit the plot. Further this map works together with the visual and textual elements of the cover and other paratextual devices (the blurb, its marketing as crime fiction, and so on) to indicate that the action of the novel will be in keeping with genre expectations. In this context the map is not a tabula rasa for the telling of just any story. To provide a map in a crime novel is to signal a particular kind of story, and vice versa.

In his stand-alone crime novel Entry Island (2014), set on the titular island in the Gulf of St Lawrence, Peter May reminds his readers that as settings, islands are not only passive backdrops for the actions of characters, but actively drive the narrative and produce meaning. In this novel May provides an exemplar of the way islands are invested with agency: "The island drew Sime's focus and held it there, almost trancelike, as the sun sent its reflection careening towards him, creating what was almost a halo effect around the island itself" (May, 2014, p. 14). As the island first draws him towards its shores, and then gradually reveals itself to him, so Detective Sime MacKenzie moves inexorably towards solving the murder that brought him the nine hundred miles from Montreal to the island. In Chris Allen's Hunter (2012) the narrative is driven by "[t]he significance of the island's strategic position in the center of the Mediterranean" which "had seen Malta be a much sought-after prize throughout all the great empires, from the Phoenicians to the British, for literally thousands of years" (Allen, 2012, p. 73). In other words, the geography of the island, its context as well as its boundedness, produces its history. Its geography and its history provides a perfect base from which to launch the maritime kidnap that the hero, Alex Morgan, must crack during the course of his hunt for Serbian war criminals, as well as the insular location which contains the principal action of the novel.

Part of the appeal of popular fiction is the consistency of the tropes employed by genre writers: in the case of genre fiction set on islands, the consistent way that tropes of islandness are used across as well as within genres. We move now from crime fiction, the genre which high literary culture most embraces, to romance fiction, unquestionably the most derided popular genre. Linda Barlow and Jayne Ann Krentz argue that it is "difficult to explain the appeal of romance novels to people who don't read them" (Barlow \& Krentz, 1992, p. 15). They draw a distinction between romance writers and readers who are expert in the "codes of romance" and "[o]utsiders" who are "unable to interpret the conventional language of the genre or to recognize in that language the symbols, images, and allusions that are the fundamental stuff of romance" (Barlow and Krentz, 1992, p. 15). The implicit insular logic in this mapping of a genre community through a distinction between insiders and outsiders will be readily understood by scholars working in the broad field of island studies.

Reading popular romance fiction with an eye on setting reveals that the genre typically charts the protagonist's move from a sense of displacement or exile to a strong feeling of belonging. For countless heroes and heroines across the many and various romance subgenres, falling in love and finding one's place in the world are twinned objectives. When considered alongside the genre's requirement for an "emotionally satisfying and optimistic ending" ("About the Romance Genre," n.d.), this spatialized narrative trajectory means that romance novels are often best characterised as stories of homecoming or return, especially when the protagonist arrives in the novel's key setting for the first time, yet feels a strong sense of 


\section{R. Crane \& L. Fletcher}

identification with or recognition of the place. The genre's valorisation of normative concepts of home and family is one explanation for the evident appeal of small islands to contemporary romance writers: time and again the happy ending is reached when hero and heroine declare both their mutual love and their shared decision to make the island their home. Importantly, however, the relative ease with which small islands facilitate the dramas of personal and social identity that are the heart of romance fiction does not explain why islands have emerged as prime locations for the genre in the twenty-first century. Whereas islands have been key "romantic locations," to use Lynne Pearce's term (Pearce, 2004, p. 533), through the genre's modern history, the enormous and increasing number of island-set contemporary romances published across the course of the last two decades suggests the existence of a genre cycle that needs greater interrogation.

The place names in Nora Roberts's Sanctuary (1997) are telling examples of how the romance genre has overlaid the map of the North American coast with genre islands, especially in the last two decades. The novel is set on the island of Lost Desire, off the coast of Georgia, "only two miles across at its widest, less than thirteen from point to point," with much of the action centred on the great house where the heroine's family runs an inn, "Sanctuary" (Roberts, 1997, location 366). Sanctuary is a stand-alone novel, a "single title" in romance industry parlance, but the island has come into its own as a stock setting for twentyfirst-century contemporary romance series.

The romantic US archipelago is growing apace with series set on real islands such as San Juan Island, in Washington's San Juan Islands archipelago, and the Massachusetts island of Nantucket, imagined versions overlaying actual islands, and entirely invented islands cropping up a short ferry ride from the mainland. Lisa Kleypas's Friday Harbor series (20102013) and Jude Deveraux's Nantucket Brides Trilogy (2013-2015) both find magic - literally and figuratively - on North American islands. Self-publishing sensation Marie Force has released sixteen novels in her series set on Gansett Island, a fictionalization of Block Island, Rhode Island. According to the author's own figures, over 2.5 million Gansett Island novels have sold since the first book, Maid for Love, was released in 2011 ("The Gansett Island Series," n.d.). Terri Osburn's four-book Anchor Island series (2013-2014) is "fully and affectionately based on the very real Ocracoke Island, North Carolina" (Osburn, 2014, location 3933). New York Times bestseller Susan Mallery has published three novels set on Blackberry Island, Washington, an imagined tourist haven in Puget Sound. The author's website even hosts a visitor's guide to this invented island, where readers can learn of the island's history, download a map, and learn of "Things to Do" on the island (berry picking, crane spotting, wine tasting).

Other fantastic projections onto the map of US coastal waters include: Susan Donovan's Bayberry Island, between Martha's Vineyard and Nantucket; Julie Ortolon's Pearl Island, a ferry ride from Galveston, Texas; Kaira Rouda's Indigo Island in the South Carolina Sea Islands; and Sarah Morgan's Puffin Island, Maine. The key characteristics of islands in contemporary romance are isolation and insulation and, in this regard, the people who seek them out (both characters and readers) seem to share the perspective Philip Vannini explicates in his study of ferry mobilities in British Columbia: "islanders opt for lifestyles which 'protect' them from the ills of less desirable places" (Vannini, 2011, p. 250). This aligns with Pearce's claim that, throughout the genre, the heroine's attraction to the hero is enhanced (or explained) by the "lifestyle" represented and promised by the geographical and social setting. She detects in romance a tendency to make settings "into a lifestyle statement which is (in 
part) the undisguised object of romance" (Pearce, 2004, p. 533). For Pearce, setting is the primary variable in the lifestyle "branding" offered by romance novels. This argument has special resonance in relation to the island romance genre cycle we have identified, not least because the novels and series so often foreground their status as "escapist" reading.

Contemporary island romance series typically centre on seasonal tourist islands where, over and again, the distinction between permanent and temporary residents is a point of contention between the hero and heroine, but, as the images on cover after cover promise, the experience of living on an island (with the sand beneath your toes and the sea breeze in your hair) brings people together. One way to categorise these novels and series is as a variation on the small-town romance, exemplified by Harlequin's American Romance line, which specifies that the central love story should be "driven by the hero's or heroine's (or both) desire to be part of a family or community" ("Harlequin American Romance - 55,000 Words," n.d), and by series such as Robyn Carr's Virgin River, set in "a rugged outpost deep in California's redwood forests," or her Thunder Point, "a small, ordinary town" on the coast of Oregon ("Virgin River," n.d.). The settings of small-town romances are, fairly obviously, central to their appeal and key to their marketing. Carr's website, for example, describes Thunder Point's "long, peaceful beach," "little marina filled mostly with fishing boats," and "bay peppered with tall haystack rocks, the crashing, frothing Pacific Ocean." Potential readers are addressed as potential visitors to Thunder Point, home to the "finest people you could ever meet, people who open their hearts - and fall in love" ("Thunder Point," n.d.). Thunder Point thus offers an American idyll and there are numerous examples of similar imagined places and communities throughout the genre, such as Jill Shalvis's Lucky Harbor in Washington State, the neighbouring towns of Gnaw Bone and Carnal in Kristin Ashley's Colorado Mountain series, or Marietta, a fictional small town in Montana created by Tule Publishing and shared by multiple authors. Island romances, however, are more than a subset of the small-town romance, not least because of the emphasis such texts place on "remove" as an aspect of mainland to island mobility.

Vannini adds "remove" to the six "sensitizing concepts" for mobility research identified by Tim Cresswell: motives, speed, rhythm, route, feel, and friction (Vannini, 2011, p. 252). Remove, Vannini explains, "refers to the temporal and spatial performance of distance in which people engage in order to separate places from one another, or to bring them closer together" (Vannini, 2011, p. 252). By taking the genre offshore, the authors and publishers of island romance exploit the touristic idealisation of the remoteness of islands at the same time as promoting the idea that a sense of remove from the larger world seems "to guarantee a more distinct collective and personal identity" (Vannini, 2011, p. 252).

Both textually and paratextually, contemporary romance depicts small islands as safe havens from the dangers and difficulties of life in the twenty-first century, as natural paradises in which the tempo of everyday life is managed by the seasons and not by the artificial routines and exigencies of the "rat race," and as contained worlds in which opportunities for genuine connectivity within one's community are increased in inverse proportion to the reduced connectivity to the mainland and the wider world. The Author's Note to Force's Maid for Love explains that Gansett Island is a version of Block Island, her "favourite place in the world",

A tiny slip of land with a Great Salt Pond in the middle, Block Island is the place time forgot. You won't find a stop light on the island or a hospital. Internet connections are 


\section{R. Crane \& L. Fletcher}

sketchy at best, and good luck finding a hotel room or a spot on the ferry for your car in the summer if you haven't planned months in advance. What you will find is peace and quiet and beaches and bluffs and quaint shops and a laid-back atmosphere that soothes the soul (Force, 2011, location 27).

Ironically, this passage highlights another aspect of the tension between generality and particularity in many contemporary romance islands: a tension between accessibility and isolation, proximity and distance, reality and fantasy. Similarly, Osburn uses her Author's Note to encourage readers to "book yourself a trip to Ocracoke Island, NC," and experience the "charm, joy, and otherworldliness of [the] lovely little wonder-island" that inspired her Anchor Island novels (Osburn, 2013, location 4319). The genre's fraught fascination with escape - fraught because the genre is so often dismissed as a vehicle for naïve escapism finds particular focus in island romance. Not only are main characters often on-the-run or in hiding from a traumatic past - including Willow Parsons in the Anchor Island series, and Nell Parsons in Nora Roberts's Three Sisters Island trilogy - but they frequently work in the tourist industry or in small businesses that are dependent on island tourism: such as inns, restaurants, bookshops, galleries, and tour operators.

This article stakes a claim for the inclusion of literary studies within island studies. It argues that the conceptual frameworks and methodologies of island studies can be enriched by engagement with literature. In particular, it makes a case for reading islands in genre fiction as a means to developing a more nuanced understanding of the meaning and significance of islands in popular fiction, as we argue in greater detail and depth across four genres (crime fiction, thrillers, romance, and fantasy) in Island Genres, Genre Islands. The ideas about islands communicated by bestselling novels in both romance and crime fiction spill beyond the bindings of books into broader cultural discourses about the world in which we live. Popular genres are undeniably sources of distraction and entertainment for billions of readers. However, they are also systems of meaning, which have an immeasurable impact on our geographical awareness and imagination.

\section{References}

Allen, C. (2012). Hunter: Intrepid 2. Sydney, Australia: Momentum.

Archer, Z. (2013). Skies of gold [Kindle]. The Ether chronicles. Sydney: Avon ImpulseHarperCollins.

Ballantyne, R. M. (2015). The coral island. Richmond VA: Valancourt Books. (Original work published 1857).

Barlow, L. \& Krantz, J. A. (1992). Beneath the surface: the hidden codes of romance. In J. A. Krentz (Ed.), Dangerous men and adventurous women: Romance writers on the appeal of romance (pp. 15-29). Philadelphia PA: University of Pennsylvania Press.

Berberich, C. (2015). Introduction. In C. Berberich (Ed.), The Bloomsbury introduction to popular fiction (pp. 1-8). London: Bloomsbury.

Bolton, S. (2009). Sacrifice. London: Corgi. (Original work published 2008)

Bolton, S. (2015). Little black lies. London: Corgi.

Brenna, H. (2012). First come twins [Kindle]. Chatswood NSW: Harlequin Mills \& Boon. 
Crane, R., \& Fletcher, L. (2014). Caves as anti-places: Robert Penn Warren's The cave and Cormac McCarthy's Child of God. Reconstruction 14(3). Retrieved from http://reconstruction.eserver.org/Issues/143/CraneFletcher.shtml

Crane, R., \& Fletcher, L. (2016). Cave genres/genre caves: Reading the subterranean thriller. In L. Fletcher (Ed.), Popular fiction and spatiality: Reading genre settings (pp. 9-24). New York: Palgrave Macmillan.

Crane, R., \& Fletcher, L. (2016). Island genres, genre islands: Conceptualization and representation in popular fiction. London: Rowman \& Littlefield International.

Cresswell, T. (2004). Place: A short introduction. Malden MA: Blackwell.

Cussler, C. (2008). Shock wave. New York: Pocket Star Books. (Original work published 1996).

Defoe, D. (2007) Robinson Crusoe. Oxford: Oxford University Press. (Original work published 1719)

Enright, J. (2012). Pago Pago tango. Las Vegas: Thomas \& Mercer.

Enright, J. (2013). Fire knife dancing. Las Vegas: Thomas \& Mercer.

Enright, J. (2014). The dead don't dance. Seattle: Thomas \& Mercer.

Enright, J. (2014). Blood jungle ballet. Seattle: Thomas \& Mercer.

Ewan, C. (2012). Safe house. London: Faber.

Ewan, C. (2014). Dark tides. London: Faber.

Fletcher, L. (2011). ' $\ldots$ some distance to go': a critical survey of island studies. New Literatures Review, 47-48, 17-34.

Force, M. (2011). Maid for love [Kindle]. The McCarthys of Gansett Island. n.p.: HTJB.

The Gansett Island series. (n. d.). Marie Force. Retrieved from https://marieforce.com/books/

Gelder, K. (2004). Popular fiction: The logics and practices of a literary field. London: Routledge.

Glover, D. (2012). Publishing, history, genre. In D. Glover \& S. McCracken (Eds.), The Cambridge companion to popular fiction (pp. 15-32). Cambridge: Cambridge University Press.

Glover, D., \& McCracken, S. (2012). Introduction. In D. Glover \& S. McCracken (Eds.), The Cambridge companion to popular fiction (pp. 1-14). Cambridge: Cambridge University Press.

Golding, W. (1954). Lord of the flies. London: Faber.

Harlequin American romance - 55,000 Words. (n.d.). Write for Harlequin. Retrieved from https://harlequin.submittable.com/submit/28674

Hay, P. (2006). A phenomenology of islands. Island Studies Journal 1(1), 19-42. Retrieved from $\quad$ http://www.islandstudies.ca/sites/vre2.upei.ca.islandstudies.ca/files/u2/ISJ-1-12006-Hay-pp19-42.pdf

Hones, S. (2011). Literary geography: setting and narrative space. Social and Cultural Geography 12(7), 685-699.

Hones, S. (2008). Text as it happens: literary geography. Geography Compass 2(5), 13011317.

Hughes, C. (2011). Murder on Moloka'i. Kailua, HI: Slate Ridge. (Original work published 2004)

James, E. L. (2011). Fifty shades of grey. New York: Vintage.

James, P. D. (2005). The lighthouse. London: Faber.

Kent, G. W. (2011). Devil-devil. London: Robinson. 
Larsson, S. (2008). The girl with the dragon tattoo. London: MacLehose/Quercus. (Original work published 2005)

Leane, E. (2016). Unstable places and generic spaces: thrillers set in Antarctica. In L. Fletcher (Ed.), Popular fiction and spatiality: Reading genre settings (pp. 25-43). New York: Palgrave Macmillan.

McCall, G. (1994). Nissology: a proposal for consideration. Journal of the Pacific Society 17(2-3), 1-14.

McCall, G. (1996) Nissology: a debate and discourse from below. Retrieved from http://southpacific.arts.unsw.edu.au/resources/resource_nissology.htm.

McMahon, B. (1992). Island paradise. Richmond: Mills \& Boon.

May, P. (2014). Entry Island. London: Quercus.

Osburn, T. (2013). Meant to be [Kindle]. Anchor Island. Las Vegas, NV: Montlake Romance.

Osburn, T. (2014). More to give [Kindle]. Anchor Island. Seattle: Montlake Romance.

Owen, D. (2003). Pig's head. Sydney: Arrow. (Original work published 1994)

Parv, V. (1989). Tasmanian devil. Richmond: Mills \& Boon.

Parv, V. (2004). The art of romance writing: Practical advice from an international bestselling romance writer (Rev. edn.) [Kindle]. Crows Nest, NSW: Allen \& Unwin.

Pearce, L. (2004). Popular romance and its readers. In C. Saunders (Ed.), A companion to romance: from classical to contemporary (pp. 521-538). Malden MA: Blackwell.

Pearce, L. (2007). Romance writing. Cambridge: Polity.

Pezzotti, B. (2012). The importance of place in contemporary Italian crime fiction: a bloody journey. Madison NJ: Fairleigh Dickinson University Press.

Pratt, M. L. (1992). Imperial eyes: Travel writing and transculturation. London: Routledge.

Roberts, N. (n.d.) Treasures lost, treasures found [Kindle]. Chatswood, NSW: Harlequin Mills $\&$ Boon. (Original work published 1986)

Roberts, N. (2008). Sanctuary [Kindle]. London: Hachette Digital. (Original work published 1997)

Robertson, C. (2014). The last refuge. London: Simon \& Schuster.

Schmid, D. (2012). From the locked room to the globe: space in crime fiction. In V. Miller \& H. Oakley (Eds.), Cross-cultural connections in crime fictions (pp. 7-23). Houndsmills: Palgrave Macmillan.

Shakespeare, W. (2008). The Tempest. Oxford: Oxford University Press. (Original work performed 1611)

Snow, E. (2013). Tidal. New York: Touchstone. (Original work performed 2012)

Stevenson, R. L. (2011) Treasure Island. Oxford: Oxford University Press. (Original work performed 1883)

Stone, N. (2011). Mr Clarinet. London: Penguin. (Original work published 2006)

Tally Jr., R. T. (2013). Spatiality. London: Routledge.

Thunder Point. (n. d.). Robyn Carr. Retrieved from http://www.robyncarr.com/series/thunderpoint/

Turner, L., \& Ash, J. (1975). The golden hordes: International tourism and the pleasure periphery. London: Constable.

Vannini, P. (2011). Constellations of ferry (im)mobility: islandness as the performance and politics of insulation and isolation. Cultural Geographies 18(2), 249-271.

Virgin River. (n. d.). Robyn Carr. Retrieved from http://www.robyncarr.com/series/virgin$\underline{\text { river/ }}$ 